\title{
Mechanisms of Surface Charge Modification of Carbonates in Aqueous Electrolyte Solutions
}

\author{
Maryam H. Derkani ${ }^{1}\left(\mathbb{D}\right.$, Ashleigh J. Fletcher ${ }^{1}$ (D), Maxim Fedorov ${ }^{2}$, Wael Abdallah ${ }^{3}$, \\ Bastian Sauerer ${ }^{3}$, James Anderson ${ }^{4}$ and Zhenyu J. Zhang ${ }^{5, * \mathbb{D}}$ \\ 1 Department of Chemical and Process Engineering, University of Strathclyde, Glasgow G1 1XJ, UK; \\ maryam.derkani@strath.ac.uk (M.H.D.); ashleigh.fletcher@strath.ac.uk (A.J.F.) \\ 2 Department of Physics, Scottish Universities Physics Alliance (SUPA), University of Strathclyde, \\ 107 Rottenrow East, Glasgow G4 0NG, UK; maxim.fedorov@strath.ac.uk \\ 3 Schlumberger Middle East, S.A., Schlumberger Dhahran Carbonate Research Center, Dhahran Techno Valley, P.O. \\ Box 39011, Dammam 31942, Saudi Arabia; wabdallah@slb.com (W.A.); bsauerer@slb.com (B.S.) \\ 4 Chemical and Materials Engineering Group, School of Engineering, University of Aberdeen, \\ Aberdeen AB24 3UE, UK; j.anderson@abdn.ac.uk \\ 5 School of Chemical Engineerin, University of Birmingham, Birmingham B15 2TT, UK \\ * Correspondence: Z.J.Zhang@bham.ac.uk
}

Received: 3 August 2019; Accepted: 22 October 2019; Published: 6 November 2019

\begin{abstract}
The influence of different types of salts $\left(\mathrm{NaCl}, \mathrm{CaCl}_{2}, \mathrm{MgCl}_{2}, \mathrm{NaHCO}_{3}\right.$, and $\left.\mathrm{Na}_{2} \mathrm{SO}_{4}\right)$ on the surface characteristics of unconditioned calcite and dolomite particles, and conditioned with stearic acid, was investigated. This study used zeta potential measurements to gain fundamental understanding of physico-chemical mechanisms involved in surface charge modification of carbonate minerals in the presence of diluted salt solutions. By increasing the salt concentration of divalent cationic salt solution $\left(\mathrm{CaCl}_{2}\right.$ and $\left.\mathrm{MgCl}_{2}\right)$, the zeta potential of calcite particles was altered, resulting in charge reversal from negative to positive, while dolomite particles maintained positive zeta potential. This is due to the adsorption of potential-determining cations $\left(\mathrm{Ca}^{2+}\right.$ and $\left.\mathrm{Mg}^{2+}\right)$, and consequent changes in the structure of the diffuse layer, predominantly driven by coulombic interactions. On the other hand, chemical adsorption of potential-determining anions $\left(\mathrm{HCO}_{3}^{-}\right.$and $\left.\mathrm{SO}_{4}^{2-}\right)$ maintained the negative zeta potential of carbonate surfaces and increased its magnitude up to $10 \mathrm{mM}$, before decreasing at higher salt concentrations. Physisorption of stearic acid molecules on the calcite and dolomite surfaces changed the zeta potential to more negative values in all solutions. It is argued that divalent cations $\left(\mathrm{Ca}^{2+}\right.$ and $\mathrm{Mg}^{2+}$ ) would result in positive and neutral complexes with stearic acid molecules, which may result in strongly bound stearic acid films, whereas ions resulting in negative mineral surface charges $\left(\mathrm{SO}_{4}^{2-}\right.$ and $\mathrm{HCO}_{3}^{-}$) will cause stearic acid films to be loosely bound to the carbonate mineral surfaces. The suggested mechanism for surface charge modification of carbonates, in the presence of different ions, is changes in both distribution of ions in the diffuse layer and its structure as a result of ion adsorption to the crystal lattice by having a positive contribution to the disjoining pressures when changing electrolyte concentration. This work extends the current knowledge base for dynamic water injection design by determining the effect of salt concentration on surface electrostatics.
\end{abstract}

Keywords: calcite; dolomite; stearic acid; zeta potential; electric double layer; disjoining pressure; wettability mechanism; low salinity waterflooding 


\section{Introduction}

Low Salinity Waterflooding (LSW) is an enhanced oil recovery strategy that injects water, of a controlled ionic concentration and composition, into oil reservoirs [1-3], potentially yielding up to $40 \%$ extra hydrocarbon, depending on conditions and crude oil properties [1,4]. Even though LSW has been demonstrated as a promising approach to improve oil recovery factors, the principal mechanisms involved are not fully understood. It has been argued that there may be more than one mechanism, or even an undiscovered mechanism, involved in LSW in carbonates [5]. Although wettability alteration, towards a more desirable state for oil to be recovered, is widely accepted as the main reason to improve oil recovery during LSW [6-11], the question of how this alteration happens is still the subject of debate, with no single design fitting all reservoirs. Understanding the wettability mechanism involved in LSW, under controlled laboratory conditions, and the colloidal interactions at oil-rock-brine interfaces are essential in improving the efficiency of LSW.

The surface charges at rock-brine and oil-brine interfaces are an essential factor to better understand the stability of the water film at oil-rock interfaces and, therefore, the degree of rock wettability. Electrostatic attraction between rock-brine and oil-brine interfaces will result in screening of the electric double layers (EDLs) at two interfaces; therefore, the water film on the rock surface will collapse and oil will come into contact with the carbonate mineral surface, consequently trapping hydrocarbons in the reservoir rock pores by creating an oil-wet state and reducing the oil recovery efficiency. The origin of the surface charge is dependent on the nature of the surfaces, as well as the surrounding environment. The three main proposed mechanisms for the origin of surface electric charges are deprotonation/protonation of surface groups (acidic or basic groups), preferential dissolution of ions from the crystal lattice, and differential adsorption of ionic species (ions or ionic surfactants) from an electrolyte solution [12]. Reducing the brine concentration/adjusting the brine composition can result in repulsive electrostatic forces at rock-brine and oil-brine interfaces and EDLs will expand to become more diffuse, which has a positive contribution to the disjointing pressure and facilitates the formation of a thicker and more stable water film [5]. This prevents oil from adhering to the rock surface. Thus, wettability of a rock is a function of the sign and magnitude of the electric surface charges at the two interfaces, which arise from the repulsive or attractive electrostatic forces at oil-rock-brine interfaces.

Zeta potential measures the electrical potential at the diffuse (outer) layer and is an essential parameter used to evaluate the electrokinetic behaviour of oil-rock-brine interfaces. It is believed that the zeta potential of carbonate surfaces can be modified by the concentrations of two types of ions, counter ions (potential-determining ions (PDIs)) that adsorb strongly onto the surface, controlling both EDL thickness and mineral surface charge, and other ions (indifferent ions) that solely control the thickness of the EDL [13]. In other words, PDIs are the ions that both produce and control the surface charge, while indifferent ions control expansion of the double layer in the solution, but are not involved in any specific interactions with the surface [14]. Therefore, the adsorption of specifically adsorbed ions on the surface can be an interplay between both forces (chemical or physical) and electrical potential [14]. Additionally, specifically adsorbed ions are identified by their ability to reverse the sign of zeta potential, while indifferent ions can only reduce zeta potential towards zero [14].

The isoelectric point (IEP) is the $\mathrm{pH}$ value at which the magnitude of positive and negative surface charges are equal. Therefore, at the IEP, the particle surface is electrically neutral and the magnitude of zeta potential is equal to zero [15]. At the IEP, electrostatic repulsion is diminished and aggregation is facilitated by van der Waals forces [16]. The point of zero charge (PZC) is determined by a particular concentration of PDI (or pH) at which the surface charge of the particle is equal to zero [14]. At the PZC, the surface charge is independent of the concentration of supporting electrolyte assuming there is no specific adsorption of 
ions [14]. It should be noted that IEP and PZC may or may not be equal. In the absence of ion adsorption from the solution (apart from ions present in the crystal lattice), the IEP and PZC can be coincident [15].

The effect of PDIs $\left(\mathrm{Ca}^{2+}, \mathrm{Mg}^{2+}\right.$ and $\left.\mathrm{SO}_{4}^{2-}\right)$ on surface charge and wetting properties of chalk was studied by Austad and co-workers [17-20], using zeta potential measurements, which complemented their chromatographic adsorption and imbibition studies at elevated temperatures. It was proposed that adsorption of $\mathrm{SO}_{4}^{2-}$ on the chalk surfaces, as well as co-adsorption of cations $\left(\mathrm{Ca}^{2+}\right.$ and $\left.\mathrm{Mg}^{2+}\right)$ in the presence of $\mathrm{SO}_{4}^{2-}$, enhanced by increasing temperature and formation of complexes between $\mathrm{Ca}^{2+}$ and carboxylic acid molecules, are the chemical mechanisms for surface charge modification and desorption of carboxylic materials. Also, it was found that $\mathrm{Mg}^{2+}$ ions can substitute $\mathrm{Ca}^{2+}$ ions from chalk surfaces at high temperature and displace surface bound $\mathrm{Ca}^{2+}$ ions that are also bonded to carboxylic acid molecules, causing them to be released in the form of calcium-carboxylate complexes, thereby further improving oil recovery. Gomari et al. [21,22] observed surface charge modification of calcite from positive to negative in the presence of carboxylic acid materials, and an ability for $\mathrm{SO}_{4}^{2-}$ and $\mathrm{Mg}^{2+}$ ions to release adsorbed fatty acids from the calcite surface. Similarly, Mahani and co-workers suggested that surface charge alteration is likely to be the main mechanism for LSW in carbonates [23-25]. It was observed that, regardless of the carbonate rock type, zeta potential is positive for high salinity formation water, while low salinity brine leads to more negative surface charges and more water-wet conditions. Furthermore, it was argued that ions causing positive carbonate surface charges are likely to change calcite wettability toward a more oil-wet condition, whereas negatively charged minerals increase oil recovery by releasing trapped crude oil molecules $[13,26]$.

The effect of mixtures of ions $\left(\mathrm{Ca}^{2+}, \mathrm{Mg}^{2+}\right.$ and $\left.\mathrm{SO}_{4}^{2-}\right)$ on calcite and dolomite conditioned with stearic acid using zeta potential measurements was examined by Kasha et al. [27]. The results indicated that, as the concentration of divalent $\mathrm{Ca}^{2+}$ and $\mathrm{Mg}^{2+}$ ions increases, the zeta potential of the conditioned calcite was altered from negative to positive, while the $\mathrm{SO}_{4}^{2-}$ ions caused the zeta potential to be more negative. They argued that the affinity of $\mathrm{Ca}^{2+}, \mathrm{Mg}^{2+}$ and $\mathrm{SO}_{4}^{2-}$ ions is affected by the presence of other potential-determining ions when using mixtures of ions. Additionally, Yousef et al. $[28,29]$ confirmed that surface charge alteration of calcite toward more negative values, in the presence of diluted seawater, results in greater interactions with water molecules, and rock wettability alteration. Similarly, zeta potentials of calcite and dolomite surfaces conditioned with stearic acid are studied using synthetic diluted seawater [30]. It was shown that the calcite surfaces maintained negative zeta potential in the presence of deionised water, and in all the tested brines, excluding diluted seawater with higher concentration of cations $\left(\mathrm{Ca}^{2+}\right.$ and $\mathrm{Mg}^{2+}$ ), which resulted in a positive zeta potential. In contrast, dolomite surfaces showed positive zeta potential in deionised water and diluted brines, except for diluted seawater containing added $\mathrm{SO}_{4}^{2-}$ ions. It was concluded that diluted seawater is less efficient in altering the surface charge of dolomite surfaces, due to the tendency of stearic acid to adsorb more strongly on dolomite surfaces. In a different work, Jackson et al. [31] measured zeta potentials of rock-brine and oil-brine interfaces interpreted from streaming potential measurements by coreflooding experiments using a limestone core sample and various oil components, to investigate the effect of different salts $\left(\mathrm{NaCl}, \mathrm{CaCl}_{2}, \mathrm{MgCl}_{2}\right.$, and $\left.\mathrm{Na}_{2} \mathrm{SO}_{4}\right)$ on wettability alteration and oil recovery. They suggested that, in order to design an optimum brine composition for LSW in carbonates, the zeta potentials of both mineral-brine and oil-brine systems must be taken into account. It was concluded that LSW results in oil recovery improvement only if two mineral-brine and oil-brine interfaces have the same sign of zeta potential (both positive or both negative), which results in repulsive electrostatic forces and stabilises the water film on the mineral surface.

In the present work, the charging behaviour of not only natural calcite, but also dolomite particles has been studied by experimental zeta potential and $\mathrm{pH}$ measurements. The tests were conducted with, and without, the presence of a model oil component (stearic acid) as a function of individual electrolyte concentration of an indifferent monovalent cation $(\mathrm{NaCl})$, as well as using potential-determining cations 
$\left(\mathrm{CaCl}_{2}\right.$ and $\left.\mathrm{MgCl}_{2}\right)$ and potential-determining anions $\left(\mathrm{NaHCO}_{3}\right.$ and $\left.\mathrm{Na}_{2} \mathrm{SO}_{4}\right)$, including the highest concentration of these salts present in seawater $(0-100 \mathrm{mM}$, except for $\mathrm{NaCl})$. Studies were undertaken at natural $\mathrm{pH}$, allowing the effect of electrolytic concentration to be determined.

The results from this detailed and systematic study allow a better understanding of the physico-chemical mechanisms of the oil-rock-brine interfaces in these complicated, multicomponent systems to be established. Subsequently, this manuscript utilises experimental measurements to comprehensively discuss the mechanisms of surface charge modification of carbonates, such as adsorption of different ions and stearic acid molecules on the calcite and dolomite surfaces, as well as mechanisms of interactions between stearic acid molecules and the ions present in the solutions.

\section{Materials and Methods}

\subsection{Materials}

Iceland spar calcite crystals (Creel, Chihuahua, Mexico) and dolomite crystals (Butte, MT, USA) were purchased from Ward's Natural Science. Calcite (limestone) and dolomite crystals were crushed to fine powders with average diameters of 2.2 and $1.2 \mu \mathrm{m}$ for calcite and dolomite, respectively (measured by dynamic light scattering with back scatter detection (optical arrangement of $173^{\circ}$ )). The model oil component was prepared by addition of $0.071 \mathrm{~g}$ stearic acid $\left(\mathrm{CH}_{3}\left(\mathrm{CH}_{2}\right)_{16} \mathrm{COOH}\right)$ (Sigma-Aldrich, UK) to $8.1 \mathrm{~mL}$ of toluene $\left(\mathrm{C}_{6} \mathrm{H}_{5}\left(\mathrm{CH}_{3}\right)\right)$ (Sigma-Aldrich, $\mathrm{UK}$ ), which corresponds to a stearic acid concentration of $8.77 \mathrm{mg} / \mathrm{g}(\mathrm{kppm})$ with a total acid number (TAN) of $2.0 \mathrm{mg} \mathrm{KOH} / \mathrm{g}$. TAN is a measurement of acidity that is determined by the amount of potassium hydroxide in milligrams that is needed to neutralise the acids in one gram of oil. The mixture was agitated for $24 \mathrm{~h}$ to ensure full dissolution of stearic acid in toluene. Five different salts (ACS reagent grade), namely sodium chloride $(\mathrm{NaCl})$, calcium chloride $\left(\mathrm{CaCl}_{2}\right)$, magnesium chloride $\left(\mathrm{MgCl}_{2}\right)$, sodium bicarbonate $\left(\mathrm{NaHCO}_{3}\right)$, and sodium sulphate $\left(\mathrm{Na}_{2} \mathrm{SO}_{4}\right)$, were purchased from Sigma-Aldrich to prepare synthetic seawater. Table 1 shows the concentrations of the studied salts in prepared seawater.

Table 1. Concentration of salts in prepared seawater, based on concentrations native to the Persian Gulf [5].

\begin{tabular}{cccc}
\hline Salt & Conc. (g/L) & Conc. (ppm) & Conc. (mM) \\
\hline $\mathrm{NaCl}$ & 40.30 & 40,323 & 690 \\
$\mathrm{CaCl}_{2}$ & 1.79 & 1799 & 16.20 \\
$\mathrm{MgCl}_{2}$ & 8.46 & 8461 & 88.80 \\
$\mathrm{Na}_{2} \mathrm{SO}_{4}$ & 6.58 & 6580 & 46.30 \\
$\mathrm{NaHCO}_{3}$ & 0.16 & 165 & 1.96 \\
\hline
\end{tabular}

\subsection{Sample Preparation}

Carbonate samples (calcite and dolomite powders) were washed with deionised water (HPLC grade, Sigma-Aldrich). The suspensions were agitated using an orbital shaker for $24 \mathrm{~h}$ to allow soluble particles to dissolve in water. The remaining carbonate samples were separated from water using filter paper and dried in a vacuum oven over night at $80^{\circ} \mathrm{C}$.

Stearic acid-conditioned carbonate samples were prepared by addition of $0.81 \mathrm{~g}$ washed calcite/dolomite powder to $8.1 \mathrm{~mL}$ of the prepared model oil component. The container was agitated for $24 \mathrm{~h}$ at room temperature allowing stearic acid to adsorb on carbonate surfaces. The contents were filtered through filter paper and the stearic acid-conditioned powders were dried at room temperature in an open container in a fume cupboard. 
Aqueous electrolyte solutions $(100 \mathrm{mM})$ were freshly prepared on the day of experimentation. Lower concentrations of each salt solution were prepared by diluting solutions from $100 \mathrm{mM}$ to 10,1, 0.1 , and $0.01 \mathrm{mM}$, as required. Dissolved $\mathrm{CO}_{2}$ was removed from the system by bubbling a stream of nitrogen gas through the HPLC grade water for $1 \mathrm{~h}$, prior to salt solution preparation; the $\mathrm{pH}$ was checked to ensure gas removal. Additionally, ingress of atmospheric $\mathrm{CO}_{2}$ to the samples was minimised by using sealed containers throughout sample preparation and measurements.

Samples for zeta potential measurements were prepared by adding $0.005 \mathrm{~g}$ of unconditioned or model oil component conditioned calcite/dolomite powder into $5 \mathrm{~mL}$ of each electrolyte solution (giving a final loading of $1 \mathrm{mg} / \mathrm{mL}$ ). The suspension was agitated using an orbital shaker for $1 \mathrm{~h}$ to ensure complete interaction of ions with the surfaces, and to allow equilibrium to be established. It was shown by Nyström et al. [32] that 30-60 min of agitation is sufficient for the system to reach the solubility limit of calcite, while other authors $[33,34]$ argued that zeta potential of calcite particles became steady with time as a result of attaining chemical equilibrium. However, our experimental measurements showed no rapid changes in zeta potential of carbonate particles over time after $1 \mathrm{~h}$ of agitation and is a valid representation of equilibrium conditions.

\subsection{X-ray Diffraction}

X-ray powder diffraction of the calcite and dolomite powders was undertaken using a BRUKER D8 ADVANCE with DAVINCI (2010) X-ray Diffractometer with a Cu radiation source in the range $20^{\circ}$ to $90^{\circ}$, with a step size of $0.02^{\circ}$.

\subsection{Fourier Transform Infrared Spectroscopy}

Attenuated Total Reflectance Fourier Transform Infrared (ATR-FTIR) spectra of unconditioned and model oil conditioned calcite and dolomite powders were measured in the range 600 to $4000 \mathrm{~cm}^{-1}$ using an ABB instrument MB3000 Series FTIR Spectrometer with Internal Reflection Element (IRE) of diamond in absorbance mode. Each spectrum was the average of 32 scans with a spectral resolution of $4 \mathrm{~cm}^{-1}$. A small quantity of unconditioned or stearic acid-conditioned calcite and dolomite powders were evenly placed on the solid ATR cell to ensure a dense coverage on the germanium crystal.

\subsection{Zeta Potential Measurements}

Zeta potentials of calcite and dolomite powders in electrolytic solutions were measured using a Malvern Zetasizer Nano ZS instrument in a closed system. Zeta potentials of colloidal dispersions were measured using laser Doppler electrophoresis. In this technique, a voltage is applied across a cell and the mobility of the particles undergoing electrophoresis is determined from the frequency shift detected for the scattered light. The conductivity and electrophoretic mobility of each sample were measured and zeta potential was calculated by applying the Henry equation [14]:

$$
U_{E}=\frac{2 E \zeta f(\kappa R)}{3 \eta}
$$

where $U_{E}$ is electrophoretic mobility, $\zeta$ is zeta potential, $E$ is dielectric constant, $\eta$ is viscosity and $f(\kappa R)$ is Henry's function (for aqueous media and moderate electrolytic concentration $f(\kappa R)$ is 1.5 , and taken from the Smoluchowski approximation [14]).

Zeta potentials of calcite and dolomite samples were measured at $25{ }^{\circ} \mathrm{C}$ and ambient pressure. A single measurement on each sample was repeated 5 times and mean values with standard deviations are reported. Measurements were repeated using additionally prepared samples to ensure consistency of results. Disposable capillary cells were used for all zeta potential measurements. The cells and instrument 
were calibrated using a solution of polystyrene Latex beads (Sigma-Aldrich, UK) in $0.1 \mathrm{mM}$ aqueous sodium chloride solution. $\mathrm{pH}$ values were not specifically set for the solutions, and sample $\mathrm{pH}$ was measured using a HANNA pH meter (calibrated before each set of measurements using two buffer solutions with $\mathrm{pH}$ of 7.01 and 10.01).

\section{Results and Discussion}

\subsection{X-ray Diffraction}

X-ray diffraction (XRD) analysis was conducted to determine whether other crystalline phases were present in the calcite and dolomite samples. Figure 1 presents the XRD difractograms, comparing the calcite and dolomite samples used in this study with the corresponding pure compounds.
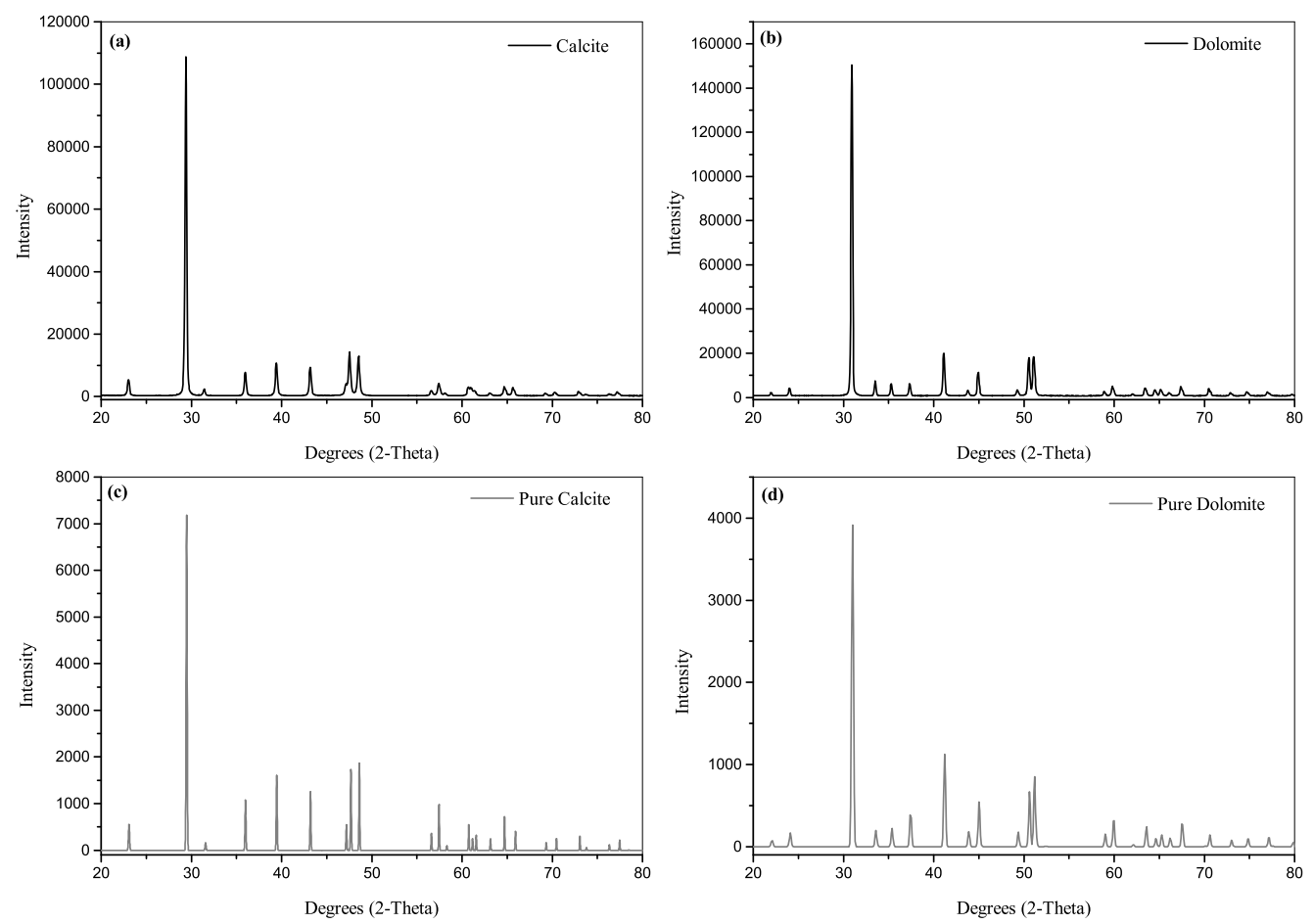

Figure 1. X-ray diffraction (XRD) patterns of the calcite (a) and dolomite (b) powders used in this study mapped with pure materials (c,d). Top: Samples employed in this work. Bottom: Reference data from literature $[35,36]$.

XRD results acquired for the calcite sample, show a dominant peak at $29.48^{\circ}$, which corresponds to a known reflection for calcite. The main peak observed in the XRD pattern of the dolomite sample is $31.07^{\circ}$, corresponding to a known reflection for dolomite. The calcite sample showed very high purity $(\sim 100 \%)$, while a small percentage of impurities $(<4 \%)$, such as quartz and ankerite, was detected in dolomite sample. These difractograms are consistent with those reported in the literature for pure calcite [35] and dolomite [36] crystals, which confirms the mineralogy of the samples used in the present study.

\subsection{ATR-FTIR Spectroscopy}

In order to examine the functional groups present on the carbonate surfaces, ATR-FTIR spectroscopy was performed in an ambient environment. Figure 2a presents IR spectra of the unconditioned calcite 
powder and samples conditioned with stearic acid, in which characteristic absorption bands, associated with carbonate groups, can be clearly identified. The bands, located at $712 \mathrm{~cm}^{-1}$ (1) and $871 \mathrm{~cm}^{-1}$ (2), are attributed to the symmetric and asymmetric $\mathrm{C}-\mathrm{O}$ bending (deformation) vibrations, respectively. The broad band centred at $1407 \mathrm{~cm}^{-1}$ (3) is associated with asymmetric C-O stretching and is one of the characteristic absorption bands of carbonate groups. These results are in agreement with previous FTIR spectroscopy of calcite $[10,37,38]$.
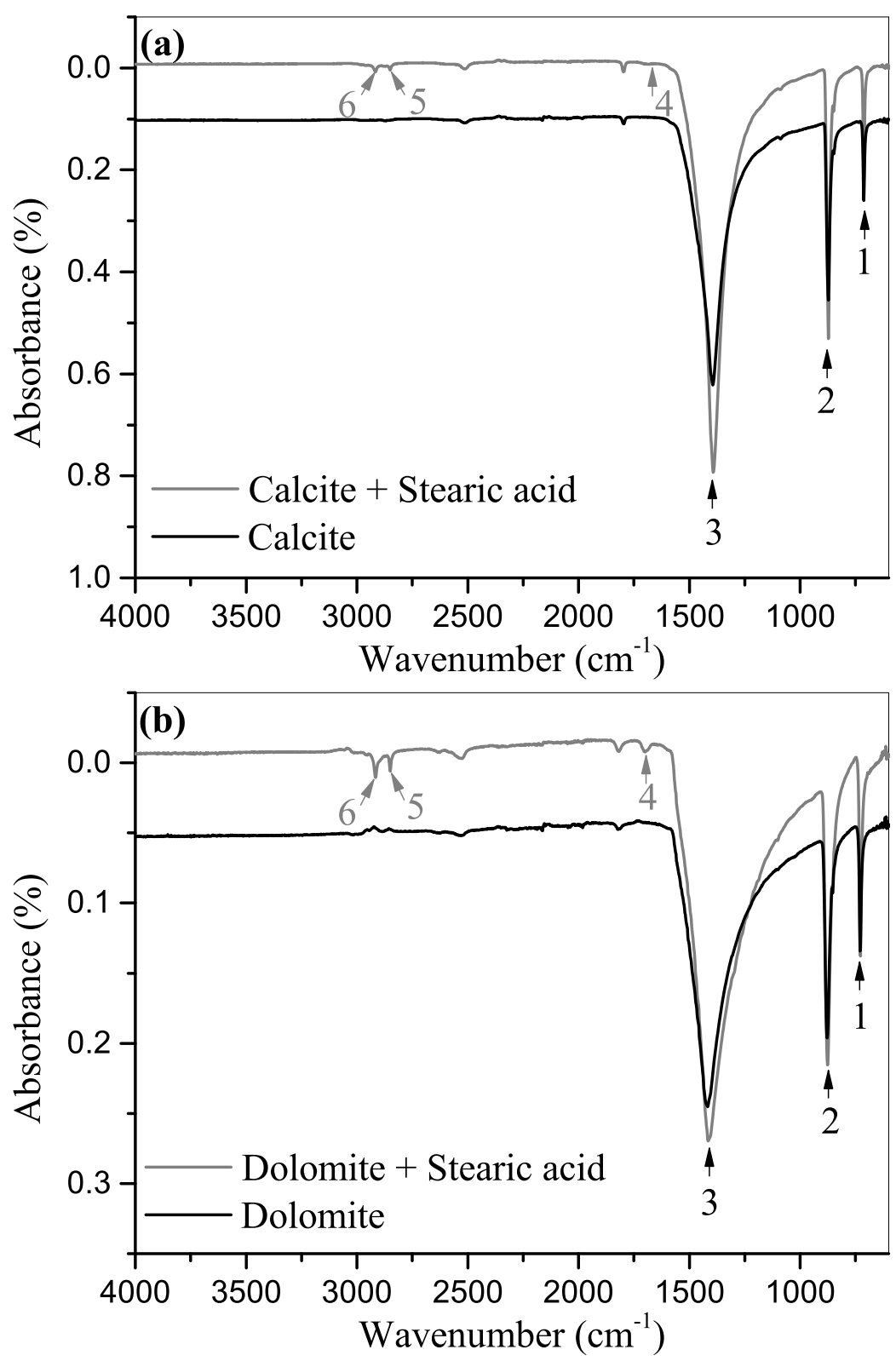

Figure 2. Comparison of Attenuated Total Reflectance Fourier Transform Infrared (ATR-FTIR) spectra of (a) unconditioned calcite and stearic acid-conditioned calcite and (b) unconditioned dolomite and stearic acid-conditioned dolomite samples. 
The treatment of calcite with stearic acid results in the observation of carboxylic group adsorption bands. The weak band located at $1670 \mathrm{~cm}^{-1}(4)$ is associated with carbonyl symmetric $\mathrm{C}=\mathrm{O}$ stretching. The absorption bands of the stearic acid alkyl chain are located at $2848 \mathrm{~cm}^{-1}$ (5), attributed to the methylene symmetric C-H stretching mode, and at $2917 \mathrm{~cm}^{-1}$ (6), associated with methylene asymmetric C-H stretching. These frequencies are in agreement with those reported in the literature [10]. Bands due to dissociated acid may be masked by the intense maxima due to the carbonate. IR spectra of dolomite powder and samples conditioned with stearic acid are shown in Figure $2 b$. The main absorption bands related to the carbonate groups of the adsorbent are: small band located at $729 \mathrm{~cm}^{-1}$ (1), attributed to symmetric $\mathrm{C}-\mathrm{O}$ bending mode; $877 \mathrm{~cm}^{-1}$ (2) assigned to asymmetric $\mathrm{C}-\mathrm{O}$ bending mode; and the broad band centred at $1417 \mathrm{~cm}^{-1}(3)$, attributed to asymmetric $\mathrm{C}-\mathrm{O}$ stretching. These results are in agreement with the literature $[38,39]$. The key features associated with the carboxylic acid groups on the dolomite (labelled 4, 5 and 6), appeared at 1700, 2842 and $2910 \mathrm{~cm}^{-1}$, respectively. These suggest molecular adsorption, although features due to dissociative adsorption of stearic acid may again have been masked by the intense maxima due to the bands of the carbonate support. The symmetric stretching vibration band of the associatively adsorbed acid $(\mathrm{COOH})$ was observed at $1700 \mathrm{~cm}^{-1}(4)$, and alkyl absorption bands of the aliphatic hydrocarbon chain are located at $2842 \mathrm{~cm}^{-1}$ (5), associated with methylene symmetric C-H stretching vibration, and at $2910 \mathrm{~cm}^{-1}$ (6), attributed to methylene asymmetric stretching vibration [40].

\subsection{Zeta Potential}

\subsubsection{Effect of Cations}

Zeta potentials of calcite and dolomite particles were measured as a function of type and concentration of salts $\left(\mathrm{NaCl}, \mathrm{CaCl}_{2}\right.$ and $\mathrm{MgCl}_{2}$ ) to examine the effect of cation valence on surface charge modification of carbonate surfaces. Zeta potential values of calcite and dolomite surfaces as a function of $\mathrm{NaCl}, \mathrm{CaCl}_{2}$ and $\mathrm{MgCl}_{2}$ aqueous electrolyte concentration, as well as measured $\mathrm{pH}$ of the solutions are shown in Figure 3. The results show that an increase in concentration of monovalent salt solution $(\mathrm{NaCl})$ results in negative surface charges for both calcite and dolomite particles, but it becomes less negative and its magnitude reduces toward zero with increasing concentration. However, for divalent cationic electrolyte solutions $\left(\mathrm{CaCl}_{2}\right.$ and $\left.\mathrm{MgCl}_{2}\right)$, the sign of zeta potential of the calcite particle is reversed from negative to positive, while dolomite surfaces maintained positive zeta potential. The positive magnitude of zeta potential increases with increasing concentration of divalent cations and, in some cases, reaches a maximum at a certain concentration (10 $\mathrm{mM}$ of $\mathrm{CaCl}_{2}$ ).

Sodium chloride is known to act as an indifferent electrolyte toward carbonate surfaces [17,41]. The current study confirms that $\mathrm{Na}^{+}$and $\mathrm{Cl}^{-}$ions adsorb on calcite and dolomite surfaces via electrostatic interactions and accumulates in the electric double layer as counter ions. Additionally, higher concentrations of $\mathrm{NaCl}$ keep the calcite and dolomite surfaces negatively charged gradually decreasing the zeta potential magnitude toward zero due to pure electrostatic screening. Both positive [32] and negative $[26,42,43]$ zeta potential of calcite particles in the presence of $\mathrm{NaCl}$ are reported in the literature. This different behaviour for calcite surface electric charges in $\mathrm{NaCl}$ solution could be due to changes in ionic strength of potential-determining ions (PDIs), such as $\mathrm{Ca}^{2+}$ in the inner Helmholtz plane, and difficulty in reaching chemical equilibrium, due to dissolution and precipitation reactions and rapid exchange rates in the presence of other ions, which results in changes in the nature of the solid surface layer $[44,45]$. Additionally, since $\mathrm{Na}^{+}$is not a PDI toward carbonate surfaces, it has been argued that an excessive amount of less hydrated $\mathrm{CO}_{3}^{2-}$ is in contact with the sample surface at high $\mathrm{pH}$, thereby resulting in negatively charged carbonate surfaces [44]. 

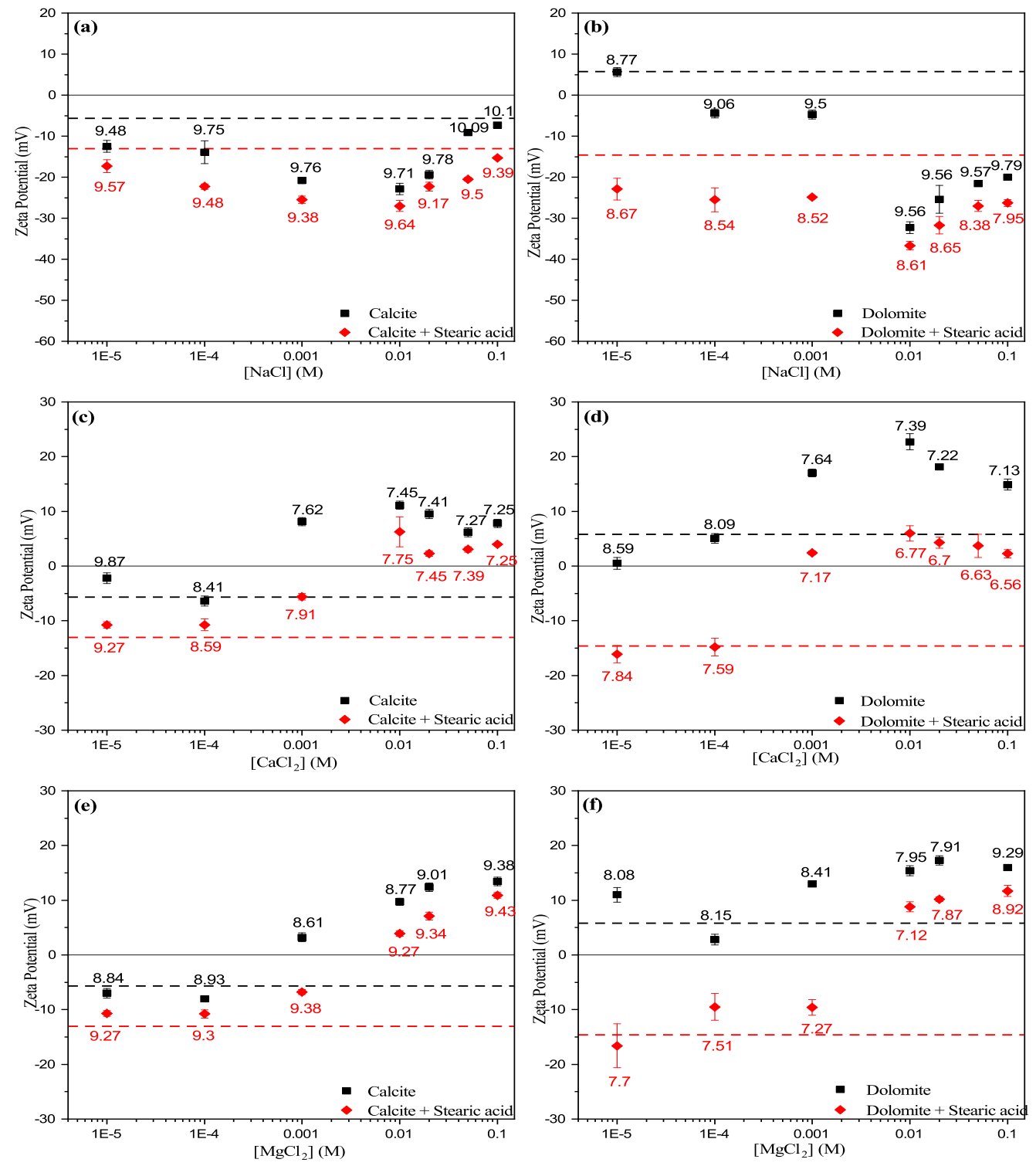

Figure 3. Comparison between the experimentally measured zeta potentials of unconditioned calcite and dolomite particles with the stearic acid-conditioned particles as a function of sodium chloride (a,b), calcium chloride (c,d), and magnesium chloride (e,f) aqueous electrolyte concentration. Measured $\mathrm{pH}$ values are reported above/below each point. Black dashed lines show zeta potential of the unconditioned carbonate particles in water and red dashed lines show zeta potential of stearic acid carbobate particles in water.

The zeta potentials of carbonate particles in the presence of divalent cationic salt solutions $\left(\mathrm{CaCl}_{2}\right.$ and $\mathrm{MgCl}_{2}$ ) showed similar behaviour, irrespective of specific ionic species. Increasing concentrations of $\mathrm{CaCl}_{2}$ and $\mathrm{MgCl}_{2}$ electrolytes reverse the zeta potetial of the calcite particle from negative to positive and increase the positive magnitude of the zeta potential of the dolomite surfaces. The positive magnitude of zeta potential of both particles, as a function of $\mathrm{CaCl}_{2}$ electrolyte concentration, reaches a maximum at $10 \mathrm{mM}$, before gradually decreasing with further increases in salt concentration. However, the positive magnitude of zeta potential continues to increase upon addition of $\mathrm{MgCl}_{2}$ electrolyte to the solutions. This 
could be due to specific adsorption of PDIs $\left(\mathrm{Ca}^{2+}\right.$ and $\left.\mathrm{Mg}^{2+}\right)$ on the carbonate mineral surfaces due to ionic interactions and mainly driven by coulombic interactions. Once adsorption reaches an equilibrium, increasing salt concentration causes surface charge to be screened and the zeta potential magnitude is subsequently reduced. Positive zeta potentials of calcite, in the presence of $\mathrm{Ca}^{2+}$ and $\mathrm{Mg}^{2+}$, are in agreement with those reported in the literature $[15,27,32,44,46]$. However, there is an inconsistency in the monolayer concentration of calcite particles by addition of $\mathrm{CaCl}_{2}$ electrolyte $(10$ or $20 \mathrm{mM})[32,46]$, and some authors [20,27], have observed a continuous increase in the magnitude of zeta potential by addition of divalent ions without noticing a maximum zeta potential at a certain concentration of divalent ions. This could be due to the fact that the maximum in the magnitude of zeta potential is caused by the competition between adsorption and screening. Therefore, different studied surfaces can result in different adsorption levels and the maximum might not be observed.

\subsubsection{Effect of Anions}

Zeta potentials of calcite and dolomite particles, as a function of $\mathrm{NaHCO}_{3}$ and $\mathrm{Na}_{2} \mathrm{SO}_{4}$ concentrations, were measured to investigate the effect of anions on surface charge modification of carbonate surfaces. Zeta potential values of calcite and dolomite surfaces as a function of $\mathrm{NaHCO}_{3}$ and $\mathrm{Na}_{2} \mathrm{SO}_{4}$ aqueous electrolyte concentration, as well as measured $\mathrm{pH}$ of the solutions, are shown in Figure 4.
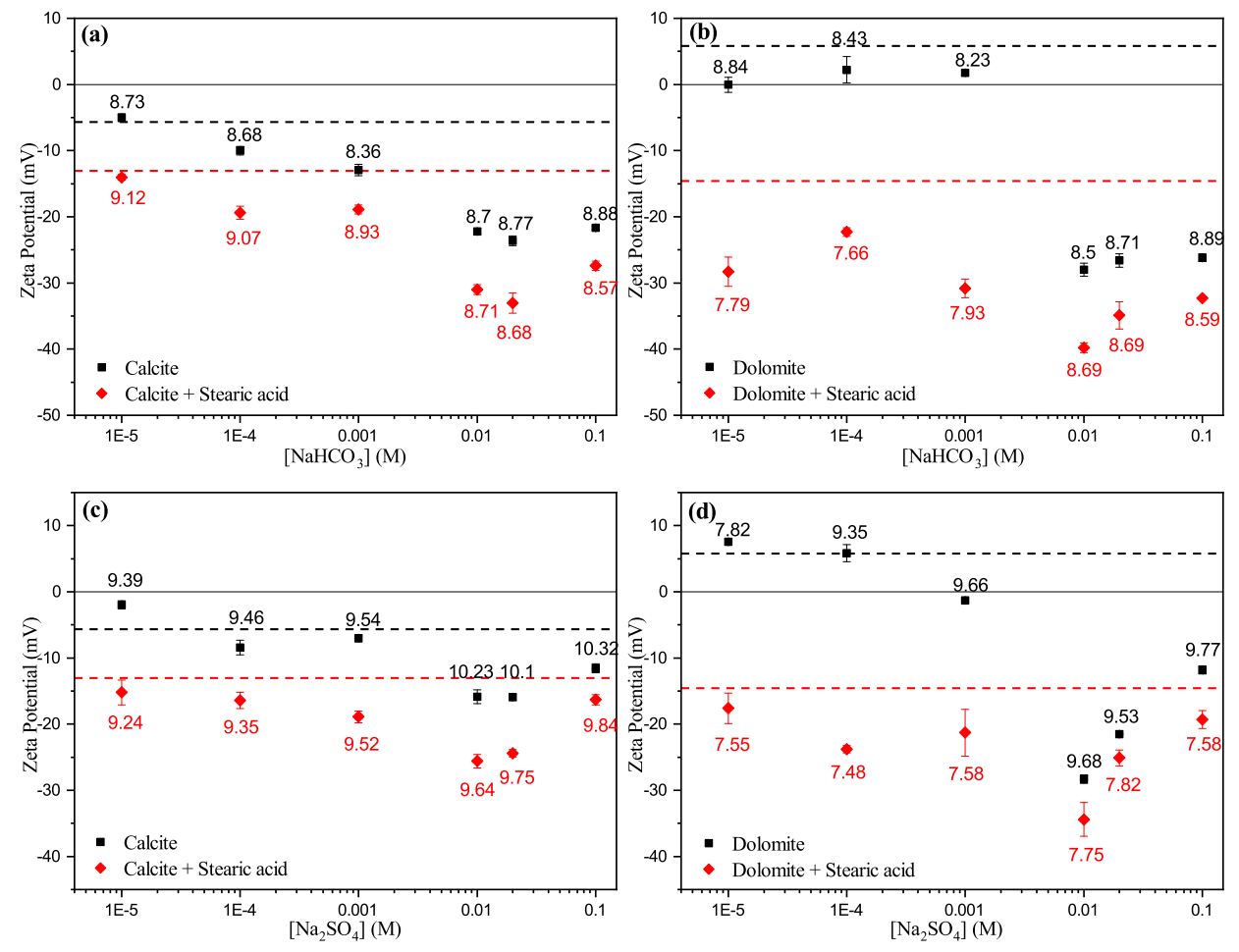

Figure 4. Comparison between the experimentally measured zeta potentials of unconditioned calcite and dolomite particles with the stearic acid-conditioned particles as a function of sodium bicarbonate (a,b), and sodium sulphate $(\mathbf{c}, \mathbf{d})$ aqueous electrolyte concentration. Measured $\mathrm{pH}$ values are reported above/below each point. Black dashed lines show zeta potential of the unconditioned carbonate particles in water and red dashed lines show zeta potential of stearic acid carbobate particles in water.

Increasing concentration of $\mathrm{NaHCO}_{3}$ and $\mathrm{Na}_{2} \mathrm{SO}_{4}$ electrolytes causes the zeta potentials of calcite and dolomite particles to decrease. The zeta potentials reduce toward more negative values until a 
concentration of 10-20 mM, due to adsorption of $\mathrm{HCO}_{3}^{-}$and $\mathrm{SO}_{4}^{2-}$ ions on carbonate surfaces. At higher concentrations of salts, zeta potential of the particles increases toward less negative values. The mechanisms of adsorption of sulphate ions on calcite surfaces could be due to interaction with crystal lattice cations, as well as specific adsorption in the Stern layer [47] or electrostatic interactions [48]. Andersen et al. [47] argued that sulphate adsorbs on calcite surfaces due to chemical interactions on the basis of experimental zeta potential measurements of calcite surfaces. It is possible that overall surface charge of carbonate surfaces are constitute of an inner and outer charged layers, which means carbonate surfaces can carry both negative charge in the outer layer and positive charge in the inner layer. Therefore, $\mathrm{HCO}_{3}^{-}$and $\mathrm{SO}_{4}^{2-}$ anions can chemically adsorb onto the positively charged inner layer of the carbonate surfaces.

The current results show that $\mathrm{HCO}_{3}^{-}$and $\mathrm{SO}_{4}^{2-}$ ions produce very similar zeta potential results, although one is monovalent and the other is divalent, meaning that electrostatics are different for both ions. However, the specific adsorption of $\mathrm{HCO}_{3}^{-}$anions seems to be stronger than for $\mathrm{SO}_{4}^{2-}$, consequently producing similar zeta potential results. Such observations have also been reported in the literature [49] for other types of particles using the same ions.

Additionally, it is likely that specific adsorption of sulphate ions on calcite and dolomite surfaces results in reduction of positive surface charges and increases electrostatic attraction between cations and anions, which allows excess calcium ions to locate closer to the surface, which assist in desorbing and releasing polar molecules of oil from the surfaces by creating calcium carboxylate complexes $[18,20,21]$.

Negative zeta potentials of calcite $[21,26,27]$ and dolomite [26] particles in the presence of sulphate ions are in agreement with those reported in the literature. However, in addition to negative surface charges, the current results show such adsorption of ions on the surface reaches a maximum value at a certain concentration (10 or $20 \mathrm{mM}$ ) before a decrease, due to electrostatic screening.

A number of previous works $[18,21,27,50]$ reported the influence of sulphate ions in modifying surface electric charge of carbonate surfaces toward more negatively charged values and, therefore, a more water-wet condition. The present study shows that bicarbonate ions, as well as sulphate ions, act as strong PDIs towards carbonate surfaces, due to specific adsorption of anions, which adsorb strongly on the carbonate surfaces and result in negative surface charges.

When calcite is exposed to water, the following reactions can occur, which result in multiple ions being present in the solution [42]:

$$
\begin{aligned}
& \mathrm{CaCO}_{3} \rightleftharpoons \mathrm{Ca}^{2+}+\mathrm{CO}_{3}^{2-} \\
& \mathrm{Ca}^{2+}+\mathrm{H}_{2} \mathrm{O} \rightleftharpoons \mathrm{Ca}(\mathrm{OH})^{+}+\mathrm{H}^{+} \\
& \mathrm{Ca}^{2+}+2 \mathrm{H}_{2} \mathrm{O} \rightleftharpoons \mathrm{Ca}(\mathrm{OH})_{2}+2 \mathrm{H}^{+} \\
& \mathrm{CO}_{3}^{2-}+\mathrm{H}_{2} \mathrm{O} \rightleftharpoons \mathrm{HCO}_{3}^{-}+\mathrm{OH}^{-} \\
& \mathrm{HCO}_{3}^{-}+\mathrm{H}_{2} \mathrm{O} \rightleftharpoons \mathrm{H}_{2} \mathrm{CO}_{3}+\mathrm{OH}^{-}
\end{aligned}
$$

Although $\mathrm{Ca}^{2+}$ and $\mathrm{CO}_{3}^{2-}$ ions are probably the PDIs in a calcite aqueous suspension [48,51-53], it has been suggested that other ions, e.g., $\mathrm{H}^{+}, \mathrm{OH}^{-}, \mathrm{CaOH}^{+}$, and $\mathrm{HCO}_{3}^{-}$could contribute towards zeta potential $[15,48,54,55]$. Furthermore, additional ions $\mathrm{Ca}^{2+}, \mathrm{Mg}^{2+}, \mathrm{SO}_{4}^{2-}$ were also suggested to play a role in determining potential $[17,20,56,57]$. Therefore, PDIs could be crystal lattice ions, ions from surface hydrolysis or protonation $\left(\mathrm{H}^{+}\right.$or $\mathrm{OH}^{-}$in the solution), or the ions added to the solution (adsorption) [15].

Increasing the $\mathrm{pH}$ of the solutions, and adding $\mathrm{OH}^{-}$ions (above the isoelectric point (IEP)), results in an excess of $\mathrm{HCO}_{3}^{-}$and $\mathrm{CO}_{3}^{2-}$ ions in the solution, and negatively charged surfaces. This causes a reduction of zeta potential toward higher $\mathrm{pH}$ and a reduction in solubility of calcite, hence, lower concentrations of $\mathrm{Ca}^{2+}[44,52]$. However, at low $\mathrm{pH}$ (below the IEP) where excessive amounts of $\mathrm{H}^{+}$ions are present, the concentration of $\mathrm{Ca}^{2+}$ ions increases and, consequently, causes the surface to be positively charged $[44,56]$. Dissolution of the carbonate crystal lattice is likely to happen when carbonate surfaces are exposed to water, which will give rise to the overall surface charge [27]. By increasing the ionic strength of the 
solution, the binding sites of the crystal surfaces are covered with PDIs, which compete for surface sites. Therefore, in the presence of PDIs in the solution, $\mathrm{pH}$ does not play an important role in electric charge modification of the carbonate surfaces [23]. Additionally, removing atmospheric $\mathrm{CO}_{2}$ from the aqueous solution will reduce the concentration of $\mathrm{HCO}_{3}^{-}$ions in the solution, which can result in reduction of $\mathrm{CO}_{3}^{2-}$, and therefore increasing calcite dissolution, due to the following equilibrium reaction:

$\mathrm{CO}_{2}+\mathrm{H}_{2} \mathrm{O} \rightleftharpoons \mathrm{HCO}_{3}^{-}+\mathrm{H}^{+}$

The IEP of calcite particles in pure water is reported in the $\mathrm{pH}$ range 7-12 [58], and the point of zero charge (PZC) lies in the $\mathrm{pH}$ range 8-9.5 [44,48] depending on material source and conditions. Both positive and negative values for calcite in water are reported in the literature. Some researchers $[10,32,46,59]$ reported positive values for the zeta potential of calcite in water, whereas others [27,42,43,60-62] reported negative values for the calcite/water suspension. This could be caused by different sources of carbonates, solution $\mathrm{pH}$, type and concentration of PDIs, dispersant concentration in water, and complex dissolution of carbonates in water $[15,42]$. We observed negative surface charges for our calcite sample in water $(-5 \mathrm{mV})$. The measured $\mathrm{pH}$ values of calcite in water solutions were recorded in the range 8-9, which are well above the IEP (5.40) and confirm the negative surface electric charges observed in our measurements.

Our results show that $\mathrm{pH}$ values of the aqueous solutions, in the presence of calcite particles and different electrolytes $\left(\mathrm{CaCl}_{2}, \mathrm{MgCl}_{2}, \mathrm{NaHCO}_{3}, \mathrm{Na}_{2} \mathrm{SO}_{4}\right)$, are in the range 7-10, which is above the measured IEP of the calcite sample (5.40) [27]. This suggests that the calcite surfaces may be negatively charged in the presence of these electrolytes. However, the experimental results showed that calcite surfaces are positively charged at higher concentrations of $\mathrm{CaCl}_{2}$ and $\mathrm{MgCl}_{2}$ salts. Therefore, it is concluded that $\mathrm{Ca}^{2+}$ and $\mathrm{Mg}^{2+}$ ions act as PDIs toward calcite surfaces and control calcite surface charges due to specific adsorption of divalent cations $\left(\mathrm{Ca}^{2+}\right.$ and $\left.\mathrm{Mg}^{2+}\right)$ on the calcite surface.

The following reactions show the main chemical species produced by dissolution of dolomite in water $[63,64]$ :

$\mathrm{CaMg}\left(\mathrm{CO}_{3}\right)_{2} \rightleftharpoons \mathrm{Mg}^{2+}+\mathrm{Ca}^{2+}+2 \mathrm{CO}_{3}^{2-}$

$\mathrm{Ca}^{2+}+\mathrm{HCO}_{3}^{-} \rightleftharpoons \mathrm{CaHCO}_{3}^{+}$

$\mathrm{CaHCO}_{3}^{+} \rightleftharpoons \mathrm{CaCO}_{3}+\mathrm{H}^{+}$

$\mathrm{Ca}^{2+}+\mathrm{OH}^{-} \rightleftharpoons \mathrm{CaOH}^{+}$

$\mathrm{CaOH}^{+}+\mathrm{OH}^{-} \rightleftharpoons \mathrm{Ca}(\mathrm{OH})_{2}$

Similarly to calcite particles, different PDIs have been claimed to control the surface charge of dolomite particles by different authors. Ions such as $\mathrm{Ca}^{2+}, \mathrm{Mg}^{2+}$ and $\mathrm{SO}_{4}^{2-}$, as well as $\mathrm{H}^{+}, \mathrm{OH}^{-}$and $\mathrm{CO}_{3}^{2-}$, are suggested to be PDIs for dolomite surfaces [27,65]. However, Predali et al. [63] argued that only $\mathrm{H}^{+}$and $\mathrm{OH}^{-}$act as PDIs for dolomite surfaces and ions such as $\mathrm{Ca}^{2+}$ and $\mathrm{Mg}^{2+}$ are indifferent ions.

At higher $\mathrm{pH}$ values (above the IEP), lower concentrations of positively charged species $\left(\mathrm{Mg}^{2+}, \mathrm{Ca}^{2+}\right.$, $\mathrm{MgOH}^{+}$and $\left.\mathrm{CaOH}^{+}\right)$, compared to negatively charged species $\left(\mathrm{HCO}_{3}^{-}\right)$, result in negative surface charges of the dolomite surfaces. However, at lower $\mathrm{pH}$ (below the IEP), higher concentrations of positively charged species lead to positive surface charges [64].

The IEP of dolomite particles in pure water lies in the $\mathrm{pH}$ range $6-8[27,64,66,67]$ and the PZC is reported in the $\mathrm{pH}$ range 6-7 [63]. Dolomite particles showed similar zeta potential trends to those for calcite particles in the presence of aqueous electrolyte solutions and adsorbed carboxylic acid. However, the dolomite surfaces mostly showed weak positive surface electric charges $(5 \mathrm{mV})$ in water. The measured $\mathrm{pH}$ values of the dolomite sample in water were recorded in the range 7-8, which is well below the IEP of this sample (above 11) [27], and confirms the positive surface electric charge of dolomite. Positive zeta potentials for dolomite particles are in agreement with those reported in the literature $[27,39,64]$.

Our results indicate that $\mathrm{pH}$ values of the aqueous solutions in the presence of dolomite particles and different electrolytes studied are in the range 7-9, which are below the IEP of dolomite (>11) [27]. This suggests that dolomite surfaces may be positively charged in the presence of these electrolytes 
(although, the experimental results showed that calcite surfaces are negatively charged in the presence of $\mathrm{NaHCO}_{3}$ and $\mathrm{Na}_{2} \mathrm{SO}_{4}$ salts). Thus, $\mathrm{HCO}_{3}^{-}$and $\mathrm{SO}_{4}^{2-}$ ions can be PDIs towards dolomite surfaces by reversing the initial zeta potential of dolomite surfaces from positive to negative.

\subsubsection{Effect of Stearic Acid}

Stearic acid-conditioned calcite surfaces, when added into water, create a surface with stronger negative charges $(-14 \mathrm{mV})$ than the calcite alone $(-5 \mathrm{mV})$. Results shows that the adsorption of stearic acid, an anionic surfactant, on a carbonate surface covers the surface with additional negatively charged functional groups and gives rise to the increased negative magnitude of zeta potentials. More negative magnitudes of zeta potential of the carbonate surfaces conditioned with stearic acid are in agreement with those previously reported in the literature $[10,11,21,27,39]$.

Our results show that carbonate surfaces conditioned with stearic acid showed similar trends to the zeta potentials of the unconditioned surfaces when increasing the ionic strength of the electrolytes, but resulted in more negative values.

A possible structure for the adsorbed stearic acid layer could be formation of a monolayer of alkyl chains, due to physisorption of the stearic acid by charge interaction of the head group with carbonate surfaces, due to steric effects, and oblique or gauche conformation of the aliphatic hydrocarbon chain, as well as physisorption of the stearic acid molecule head group to the surface by hydrogen bonds [68]. Another possible structure of the adsorbed layer could be physical adsorption of alkyl chains due to alkyl-alkyl interactions (London dispersion force), as dimers (tail-to-tail arrangement), creating the upper layer of surfactant [69]. This arrangement results in the negatively charged head groups of stearic acid molecules being exposed to the aqueous solution leading to more negative surface charges. Alternatively, the dry stearic acid treatment method of carbonate surfaces could produce stearic acid molecules that are dissociated by transfer of $\mathrm{H}^{+}$ions to the carbonate surface. Thus, stearate ions are chemically adsorbed on the initial surface centre of calcium [68], resulting in creation of a surface composed of bicarbonate and calcium stearate.

When carbonate particles, conditioned with stearic acid, are added into aqueous solution, the initially physisorbed stearic acid molecules will dissociate as a result of the $\mathrm{pK}_{a}(10.15)$ [70] and produce $\mathrm{H}^{+}$and stearate ions. Therefore, stearate anions will displace the physisorbed stearic acid molecules and create an adsorbed layer. As more stearate anions are adsorbed, the equilibrated solution will adjust, leading to the dissociation of more stearic acid molecules to recover equilibrium.

Previous studies show that the structure and stability of the stearic acid (SA) Langmuir-Blodgett (LB) film undergo changes in the presence of aqueous electrolyte solutions, depending on whether they contain mono or divalent ions, as well as on the $\mathrm{pH}$ of the solution [71,72]. At sufficiently high $\mathrm{pH}$, divalent cations compress the monolayer, forming a packed structure, therefore improving crystalline order, while monovalent cations result in a less ordered monolayer [73]. Additionally, divalent cations $\left(\mathrm{D}^{2+}\right)$ have a stabilising influence on the stearic acid film by forming different complexes with deprotonated stearic acid $\left(\mathrm{R}^{-}\right)\left(\mathrm{CH}_{3}\left(\mathrm{CH}_{2}\right)_{16} \mathrm{COO}^{-}\right)$, such as positive $\mathrm{RD}^{+}$, neutral $\mathrm{R}_{2} \mathrm{D}$, or both, by increasing the likelihood of the LB monolayer to be electrically neutral. Monovalent cations $\left(\mathrm{M}^{+}\right)$only form neutral $\mathrm{RM}$ complexes, therefore the monolayer remains mainly negatively charged due to the presence of the dissociated acid $\left(\mathrm{R}^{-}\right)$[71,74]. Bloch et al. [74] argued that divalent ions are chemically condensed on the stearic acid monolayer, whereas monovalent ions are attracted via weaker electrical forces.

The current results show that interactions between stearic acid molecules and carbonate surfaces and, therefore, the stability of the stearic acid monolayer is dependent on the presence of both divalent and monovalent ions in solution. 
When divalent cations $\left(\mathrm{Ca}^{2+}\right.$ and $\left.\mathrm{Mg}^{2+}\right)$ are deposited onto negatively charged carbonate surfaces, positively charged $\mathrm{RD}^{+}\left(\mathrm{SACa}^{+}\right.$and $\left.\mathrm{SAMg}^{+}\right)$complexes interact with negative sites on the carbonate surfaces and create strongly bound carboxylate salts. Additionally, neutral complexes of $\mathrm{R}_{2} \mathrm{D}\left(\mathrm{SA}_{2} \mathrm{Ca}\right.$ and $\mathrm{SA}_{2} \mathrm{Mg}$ ) can be stabilised via van der Waals and hydrophobic interactions between the alkyl chains, resulting in a strongly bound stearic acid film [71]. In contrast, when negatively charged carbonate mineral surfaces come into contact with monovalent cations $\left(\mathrm{Na}^{+}\right)$, a partially dissociated LB film containing negative charges forms, and the collective self-assembly of cation-stabilised complexes between stearate molecules and carbonate $\left(\mathrm{CO}_{3}^{2-}\right)$ groups is prevented, resulting in the formation of more negative surface charges and a stearic acid film loosely bound to the carbonate mineral surface. Therefore, the solid surfaces require even more cations to make up for the deficiency of positive charges at the interface. Additionally, when anions $\left(\mathrm{Cl}^{-}, \mathrm{HCO}_{3}^{-}\right.$and $\left.\mathrm{SO}_{4}^{2-}\right)$ are also present in the solution, the $\mathrm{LB}$ monolayer is even more negatively charged, resulting in a destabilising effect on the stearic acid monolayer, causing a release of adsorbed stearic acid molecules from the carbonate mineral surface.

It is also believed that the presence of cationic PDIs (e.g., $\mathrm{Mg}^{2+}$ ) in a solution will affect the ability of anionic PDIs (e.g., $\mathrm{SO}_{4}^{2-}$ ) to adsorb onto the stearic acid-conditioned calcite and dolomite surfaces [2,27]. Therefore, it is essential to propose a potential ratio between cations $\left(\mathrm{Ca}^{2+}\right.$ and $\left.\mathrm{Mg}^{2+}\right)$ and anions $\left(\mathrm{SO}_{4}^{2-}\right.$ and $\mathrm{HCO}_{3}^{-}$) in the solution to maximise surface wettability alteration of carbonate formation toward a more water-wet condition. It is also suggested that LSW can result in improved oil recovery, as long as both oil-brine and rock-brine interfaces have the same sign of zeta potential, which results in electrostatic repulsion at two interfaces, increasing the disjoining pressure, and creating a thicker and more stable water film, with consequent desorption and release of the adsorbed carboxylic materials from the carbonate rock surfaces [31]. The current results show that the zeta potential of the calcite surfaces in the presence of potential-determining anions $\left(\mathrm{NaHCO}_{3}\right.$ and $\left.\mathrm{Na}_{2} \mathrm{SO}_{4}\right)$ is altered to negative in both rock-brine and rock-oil-brine interfaces, while for the dolomite sample the negative zeta potential at two interfaces occurred at salt concentrations above $1 \mathrm{mM}$. However, when potential-determining cations $\left(\mathrm{Ca}^{2+}\right.$ and $\mathrm{Mg}^{2+}$ ) are present, the zeta potentials of the calcite and dolomite samples were positive at both the rock-brine and rock-oil brine interfaces only at higher salt concentrations (above $10 \mathrm{mM}$ ). Therefore, it is suggested that the potential-determining cations (especially $\mathrm{Mg}^{2+}$ above $1 \mathrm{mM}$ ) and anions (especially $\mathrm{Na}_{2} \mathrm{SO}_{4}$ ) may result in wettability alteration toward a more water-wet condition to improve oil recovery. More rigorous experimental works are required using mixtures of these two potential-determining cations and anions to investigate their influence on surface charge modification of carbonate formation. It should be noted that realistic reservoir conditions have a greater degree of complexity and many different chemical species are simultaneously present and compete for binding sites. Additionally, the kinetics of the thermodynamic equilibrium are different due to high temperatures and pressures. However, it is essential to study the colloidal interactions at oil-rock-brine interfaces in a controlled laboratory condition to better understand fundamental physiochemical mechanisms for wettability alteration of carbonate formation, which can be used as a basis to propose more complicated multicomponent systems to design the improved low salinity oil recovery process.

\section{Conclusions}

The charging behaviours of water-mineral (calcite and dolomite) particle interfaces, when these particles are either unconditioned or conditioned with stearic acid in the presence of a monovalent indifferent cation, potential-determining divalent cations, as well as potential-determining anions, were examined using experimental zeta potential measurements. Charge dependencies were subdivided into two major groups: those measured in solutions of cationic PDIs (Group A: $\mathrm{CaCl}_{2}$ and $\mathrm{MgCl}_{2}$ ) and those measured in solutions of anionic PDIs (Group B: $\mathrm{NaHCO}_{3}$ and $\mathrm{Na}_{2} \mathrm{SO}_{4}$ ). The dependencies within each 
group demonstrated similar behaviour; however, the two groups differed drastically from each other. It is shown that such interfacial charging properties are relevant to rock surface wettability modification and therefore to low salinity waterflooding for enhanced oil recovery processes. The following can be concluded:

- Experimental results show that the unconditioned calcite particles are negatively charged in water, whereas dolomite particles showed positive surface charges. However, both calcite and dolomite particles showed similar trends of zeta potential by increasing the salt concentration.

- Zeta potential results show that the surface electrostatic charge of carbonate can be altered to strongly negative in the presence of $\mathrm{HCO}_{3}^{-}$and $\mathrm{SO}_{4}^{2-}$ ions (Group B), while higher concentrations of $\mathrm{Ca}^{2+}$ and $\mathrm{Mg}^{2+}$ ions (Group A) resulted in charge reversal from negative to positive.

- The current results shows that $\mathrm{Ca}^{2+}$ and $\mathrm{Mg}^{2+}$ cations act as potential-determining ions for calcite surfaces, while $\mathrm{HCO}_{3}^{-}$and $\mathrm{SO}_{4}^{2-}$ anions can be strong potential-determining ions toward dolomite surfaces.

- Experimental results show that pre-adsorbed stearic acid carbonate surfaces were more negatively charged compared to the unconditioned surface for the same electrolyte. This could be due to dissociative chemisorption (deprotonation) of stearic acid molecules on the solid particles.

- It is argued that divalent cations, e.g., $\mathrm{Ca}^{2+}$ and $\mathrm{Mg}^{2+}$, would result in positive and neutral complexes with stearic acid molecules, which may result in strongly bound stearic acid film. In contrast, ions resulting in negative mineral surface charges $\left(\mathrm{SO}_{4}^{2-}\right.$ and $\left.\mathrm{HCO}_{3}^{-}\right)$will result in loosely bound stearic acid film to the carbonate mineral surface.

- The suggested mechanism in this study for surface charge modification of carbonates, in the presence of different ions, is changes in diffuse layer structure (expansion of electric double layer), due to adsorption of ions when changing electrolyte concentration.

This work shows that the potential-determining cations (especially $\mathrm{Mg}^{2+}$ above $1 \mathrm{mM}$ ) and anions (especially $\mathrm{Na}_{2} \mathrm{SO}_{4}$ ), lead to rock-brine and oil-brine interfaces having respectively the same sign of zeta potential (either both positive or negative), which can result in electrostatic repulsion and wettability alteration toward a more water-wet condition to improve oil recovery, by having a positive contribution to the disjointing pressure and facilitating the formation of a thicker and more stable water film.

Author Contributions: Conceptualization, M.H.D., M.F., W.A., B.S. and Z.J.Z.; methodology, M.H.D., A.J.F. and Z.J.Z..; validation, M.H.D., A.J.F. B.S, J.A., and Z.Z.; formal analysis, M.H.D., A.J.F., Z.J.Z.; investigation, M.H.D.; resources, W.A. and Z.J.Z.; writing-original draft preparation, M.H.D., A.J.F. and Z.J.Z; writing-review and editing, W.A., B.S. M.H.D. and Z.J.Z; supervision, A.J.F. and Z.J.Z; project administration, A.J.F.; funding acquisition, W.A. and Z.J.Z.

Funding: M.H.D. received a PhD scholarship (Ref: 120) from the Energy Technology Partnership (ETP). Z.J.Z. received the Engineering and Physical Science Research Council for funding through Impact Acceleration Account (IAA) that was distributed through the University of Birmingham.

Acknowledgments: M.H.D. thanks the Energy Technology Partnership (ETP) for the PhD scholarship (Ref: 120). Z.J.Z. and W.A. thank the Engineering and Physical Science Research Council for funding through Impact Acceleration Account (IAA) that is distributed through the University of Birmingham.

Conflicts of Interest: The authors declare that they have no conflict of interest.

\section{References}

1. Matthiesen, J.; Bovet, N.; Hilner, E.; Andersson, M.P.; Schmidt, D.; Webb, K.; Dalby, K.N.; Hassenkam, T.; Crouch, J.; Collins, I. How naturally adsorbed material on minerals affects low salinity enhanced oil recovery. Energy Fuels 2014, 28, 4849-4858. [CrossRef] 
2. Abdallah, W.; Gmira, A. Wettability assessment and surface compositional analysis of aged calcite treated with dynamic water. Energy Fuels 2013, 28, 1652-1663. [CrossRef]

3. Valori, A.; Ali, F.; Abdallah, W. In-Situ Wettability Evaluation of Dynamic Water Flooding of Carbonate Rocks Based on NMR-T2 Distribution. In Proceedings of the SPE Middle East Oil \& Gas Show and Conference, Manama, Kingdom of Bahrain, 6-9 March 2017; Society of Petroleum Engineers: Houston, TX, USA, 2017.

4. Kazankapov, N. Enhanced Oil Recovery in Caspian Carbonates with "Smart Water". In Proceedings of the SPE Russian Oil and Gas Exploration \& Production Technical Conference and Exhibition, Moscow, Russia, 14-16 October 2014; Society of Petroleum Engineers: Houston, TX, USA, 2014.

5. Derkani, M.; Fletcher, A.; Abdallah, W.; Sauerer, B.; Anderson, J.; Zhang, Z. Low salinity waterflooding in carbonate reservoirs: Review of interfacial mechanisms. Colloids Interfaces 2018, 2, 1-43. [CrossRef]

6. Gomari, K.R.; Hamouda, A.; Davidian, T.; Fargland, D. Study of the effect of acidic species on wettability alteration of calcite surfaces by measuring partitioning coefficients, IFT and contact angles. Contact Angle Wettability Adhes. 2006, 4, 351-367.

7. Gomari, K.R.; Hamouda, A. Effect of fatty acids, water composition and $\mathrm{pH}$ on the wettability alteration of calcite surface. J. Pet. Sci. Eng. 2006, 50, 140-150. [CrossRef]

8. Marathe, R.; Turner, M.L.; Fogden, A. Pore-scale distribution of crude oil wettability in carbonate rocks. Energy Fuels 2012, 26, 6268-6281. [CrossRef]

9. Sauerer, B.; Stukan, M.; Abdallah, W.; Derkani, M.H.; Fedorov, M.; Buiting, J.; Zhang, Z.J. Quantifying mineral surface energy by scanning force microscopy. J. Colloid Interface Sci. 2016, 472, 237-246. [CrossRef]

10. Karimi, M.; Al-Maamari, R.S.; Ayatollahi, S.; Mehranbod, N. Mechanistic study of wettability alteration of oil-wet calcite: The effect of magnesium ions in the presence and absence of cationic surfactant. Colloids Surf. A Physicochem. Eng. Asp. 2015, 482, 403-415. [CrossRef]

11. Gomari, K.R.; Denoyel, R.; Hamouda, A. Wettability of calcite and mica modified by different long-chain fatty acids (C 18 acids). J. Colloid Interface Sci. 2006, 297, 470-479. [CrossRef]

12. Everett, D.H. Basic Principles of Colloid Science; Royal Society of Chemistry: Cambridge, UK, 2007.

13. Alroudhan, A.; Vinogradov, J.; Jackson, M. Zeta potential of intact natural limestone: Impact of potential-determining ions Ca, Mg and SO 4. Colloids Surf. A Physicochem. Eng. Asp. 2016, 493, 83-98. [CrossRef]

14. Hunter, R.J. Zeta Potential in Colloid Science: Principles and Applications; Academic Press: New York, NY, USA, 2013; Volume 2, pp. 1-386.

15. Moulin, P.; Roques, H. Zeta potential measurement of calcium carbonate. J. Colloid Interface Sci. 2003, 261, 115-126. [CrossRef]

16. Hanaor, D.; Michelazzi, M.; Leonelli, C.; Sorrell, C.C. The effects of carboxylic acids on the aqueous dispersion and electrophoretic deposition of ZrO2. J. Eur. Ceram. Soc. 2012, 32, 235-244. [CrossRef]

17. Strand, S.; Høgnesen, E.J.; Austad, T. Wettability alteration of carbonates Effects of potential-determining ions $\left(\mathrm{Ca}^{2+}\right.$ and $\left.\mathrm{SO}_{4}^{2-}\right)$ and temperature. Colloids Surf. A Physicochem. Eng. Asp. 2006, 275, 1-10. [CrossRef]

18. Zhang, P.; Austad, T. Wettability and oil recovery from carbonates: Effects of temperature and potential-determining ions. Colloids Surf. A Physicochem. Eng. Asp. 2006, 279, 179-187. [CrossRef]

19. Zhang, P.; Tweheyo, M.T.; Austad, T. Wettability alteration and improved oil recovery in chalk: The effect of calcium in the presence of sulfate. Energy Fuels 2006, 20, 2056-2062. [CrossRef]

20. Zhang, P.; Tweheyo, M.T.; Austad, T. Wettability alteration and improved oil recovery by spontaneous imbibition of seawater into chalk: Impact of the potential-determining ions $\mathrm{Ca}^{2+}, \mathrm{Mg}^{2+}$, and $\mathrm{SO}_{4}^{2-}$. Colloids Surf. A Physicochem. Eng. Asp. 2007, 301, 199-208. [CrossRef]

21. Gomari, K.R.; Hamouda, A.; Denoyel, R. Influence of sulfate ions on the interaction between fatty acids and calcite surface. Colloids Surf. A Physicochem. Eng. Asp. 2006, 287, 29-35. [CrossRef]

22. Rezaei Gomari, K.A.; Karoussi, O.; Hamouda, A.A.a. Mechanistic study of interaction between water and carbonate rocks for enhancing oil recovery. In Proceedings of the SPE Europec/EAGE Annual Conference and Exhibition, Vienna, Austria, 12-15 June 2006; Society of Petroleum Engineers: Houston, TX, USA, 2006. 
23. Mahani, H.; Keya, A.L.; Berg, S.; Bartels, W.B.; Nasralla, R.; Rossen, W.R. Insights into the mechanism of wettability alteration by low-salinity flooding (LSF) in carbonates. Energy Fuels 2015, 29, 1352-1367. [CrossRef]

24. Mahani, H.; Keya, A.L.; Berg, S.; Nasralla, R. Electrokinetics of carbonate/brine interface in low-salinity waterflooding: Effect of brine salinity, composition, rock type, and $\mathrm{pH}$ on $\zeta$-potential and a surface-complexation model. SPE J. 2017, 22, 53-68. [CrossRef]

25. Mahani, H.; Menezes, R.; Berg, S.; Fadili, A.; Nasralla, R.; Voskov, D.; Joekar-Niasar, V. Insights into the impact of temperature on the wettability alteration by low salinity in carbonate rocks. Energy Fuels 2017, 31, 7839-7853. [CrossRef]

26. Alotaibi, M.B.; Nasr-El-Din, H.A.; Fletcher, J.J. Electrokinetics of limestone and dolomite rock particles. SPE Reserv. Eval. Eng. 2011, 14, 594-603. [CrossRef]

27. Kasha, A.; Al-Hashim, H.; Abdallah, W.; Taherian, R.; Sauerer, B. Effect of $\mathrm{Ca}^{2+}, \mathrm{Mg}^{2+}$ and $\mathrm{SO}_{4}^{2-}$ ions on the zeta potential of calcite and dolomite particles aged with stearic acid. Colloids Surf. A Physicochem. Eng. Asp. 2015, 482, 290-299. [CrossRef]

28. Yousef, A.A.; Al-Saleh, S.; Al-Jawfi, M.S. The impact of the injection water chemistry on oil recovery from carbonate reservoirs. In Proceedings of the SPE EOR Conference at Oil and Gas West Asia, Muscat, Oman, 16-18 April 2012; Society of Petroleum Engineers: Houston, TX, USA, 2012.

29. Yousef, A.A.; Al-Saleh, S.; Al-Jawfi, M.S. Improved/enhanced oil recovery from carbonate reservoirs by tuning injection water salinity and ionic content. In Proceedings of the SPE Improved Oil Recovery Symposium, Ulsa, OK, USA, 14-18 April 2012; Society of Petroleum Engineers: Houston, TX, USA, 2012.

30. Al-Hashim, H.; Kasha, A.; Abdallah, W.; Sauerer, B. Impact of modified seawater on zeta potential and morphology of calcite and dolomite aged with stearic acid. Energy Fuels 2018, 32, 1644-1656. [CrossRef]

31. Jackson, M.D.; Al-Mahrouqi, D.; Vinogradov, J. Zeta potential in oil-water-carbonate systems and its impact on oil recovery during controlled salinity water-flooding. Sci. Rep. 2016, 6, 37363. [CrossRef] [PubMed]

32. Nyström, R.; Lindén, M.; Rosenholm, J.B. The Influence of $\mathrm{Na}^{+}, \mathrm{Ca}^{2+}, \mathrm{Ba}^{2+}$, and $\mathrm{La}^{3+}$ on the $\zeta$ Potential and the yield stress of calcite dispersions. J. Colloid Interface Sci. 2001, 242, 259-263. [CrossRef]

33. Al Mahrouqi, D.; Vinogradov, J.; Jackson, M.D. Zeta potential of artificial and natural calcite in aqueous solution. Adv. Colloid Interface Sci. 2017, 240, 60-76. [CrossRef]

34. Alotaibi, M.B.; Cha, D.; Alsofi, A.M.; Yousef, A.A. Dynamic interactions of inorganic species at carbonate/brine interfaces: An electrokinetic study. Colloids Surf. A Physicochem. Eng. Asp. 2018, 550, 222-235. [CrossRef]

35. Merrill, L.; Bassett, W.A. The crystal structure of CaCO 3 (II), a high-pressure metastable phase of calcium carbonate. Acta Crystallogr. Sect. B Struct. Crystallogr. Cryst. Chem. 1975, 31, 343-349. [CrossRef]

36. Alruopn, P.L. Structural refinements of dolomite and a magnesian calcite and implications for dolomite formation in the marine environment. Am. Mineral. 1977, 62, 772-783.

37. Rodriguez-Blanco, J.D.; Shaw, S.; Benning, L.G. The kinetics and mechanisms of amorphous calcium carbonate (ACC) crystallization to calcite, via vaterite. Nanoscale 2011, 3, 265-271. [CrossRef]

38. Gunasekaran, S.; Anbalagan, G.; Pandi, S. Raman and infrared spectra of carbonates of calcite structure. J. Raman Spectrosc. 2006, 37, 892-899. [CrossRef]

39. Jarrahian, K.; Seiedi, O.; Sheykhan, M.; Sefti, M.V.; Ayatollahi, S. Wettability alteration of carbonate rocks by surfactants: A mechanistic study. Colloids Surf. A Physicochem. Eng. Asp. 2012, 410, 1-10. [CrossRef]

40. Lim, M.S.; Feng, K.; Chen, X.; Wu, N.; Raman, A.; Nightingale, J.; Gawalt, E.S.; Korakakis, D.; Hornak, L.A.; Timperman, A.T. Adsorption and desorption of stearic acid self-assembled monolayers on aluminum oxide. Langmuir 2007, 23, 2444-2452. [CrossRef] [PubMed]

41. Pierre, A.; Lamarche, J.; Mercier, R.; Foissy, A.; Persello, J. Calcium as potential-determining ion in aqueous calcite suspensions. J. Dispers. Sci. Technol. 1990, 11, 611-635. [CrossRef]

42. Monfared, A.D.; Ghazanfari, M.; Jamialahmadi, M.; Helalizadeh, A. Adsorption of silica nanoparticles onto calcite: Equilibrium, kinetic, thermodynamic and DLVO analysis. Chem. Eng. J. 2015, 281, 334-344. [CrossRef]

43. Chibowski, E.; Hołysz, L.; Wójcik, W. Changes in zeta potential and surface free energy of calcium carbonate due to exposure to radiofrequency electric field. Colloids Surf. A Physicochem. Eng. Asp. 1994, 92, 79-85. [CrossRef] 
44. Farooq, U.; Tweheyo, M.T.; Sjøblom, J.; Øye, G. Surface characterization of model, outcrop, and reservoir samples in low salinity aqueous solutions. J. Dispers. Sci. Technol. 2011, 32, 519-531. [CrossRef]

45. Ishido, T.; Mizutani, H. Experimental and theoretical basis of electrokinetic phenomena in rock-water systems and its applications to geophysics. J. Geophys. Res. Solid Earth 1981, 86, 1763-1775. [CrossRef]

46. Huang, Y.C.; Fowkes, F.M.; Lloyd, T.B.; Sanders, N.D. Adsorption of calcium ions from calcium chloride solutions onto calcium carbonate particles. Langmuir 1991, 7, 1742-1748. [CrossRef]

47. Andersen, J.; El-Mofty, S.; Somasundaran, P. Using electrophoresis for determining the mechanism of amine, sulfate and oleate adsorption on calcite. Colloids Surf. 1991, 55, 365-368. [CrossRef]

48. Somasundaran, P.; Agar, G. The zero point of charge of calcite. J. Colloid Interface Sci. 1967, 24, 433-440. [CrossRef]

49. Pavlovic, M.; Huber, R.; Adok-Sipiczki, M.; Nardin, C.; Szilagyi, I. Ion specific effects on the stability of layered double hydroxide colloids. Soft Matter 2016, 12, 4024-4033. [CrossRef] [PubMed]

50. Awolayo, A.; Sarma, H.; AlSumaiti, A.M. A laboratory study of ionic effect of smart water for enhancing oil recovery in carbonate reservoirs. In Proceedings of the SPE EOR Conference at Oil and Gas West Asia, Muscat, Oman, 31 March-2 April 2014; Society of Petroleum Engineers: Houston, TX, USA, 2014.

51. Foxall, T.; Peterson, G.C.; Rendall, H.M.; Smith, A.L. Charge determination at calcium salt/aqueous solution interface. JOurnal Chem. Soc. Faraday Trans. 1 Phys. Chem. Condens. Phases 1979, 75, 1034-1039. [CrossRef]

52. Cicerone, D.S.; Regazzoni, A.E.; Blesa, M.A. Electrokinetic properties of the calcite/water interface in the presence of magnesium and organic matter. J. Colloid Interface Sci. 1992, 154, 423-433. [CrossRef]

53. Thompson, D.W.; Pownall, P.G. Surface electrical properties of calcite. J. Colloid Interface Sci. 1989, 131, 74-82. [CrossRef]

54. Guichet, X.; Jouniaux, L.; Catel, N. Modification of streaming potential by precipitation of calcite in a sand-water system: Laboratory measurements in the $\mathrm{pH}$ range from 4 to 12. Geophys. J. Int. 2006, 166, 445-460. [CrossRef]

55. Heberling, F.; Trainor, T.P.; Lützenkirchen, J.; Eng, P.; Denecke, M.A.; Bosbach, D. Structure and reactivity of the calcite-water interface. J. Colloid Interface Sci. 2011, 354, 843-857. [CrossRef]

56. Sohal, M.A.; Thyne, G.; Søgaard, E.G. Review of recovery mechanisms of ionically modified waterflood in carbonate reservoirs. Energy Fuels 2016, 30, 1904-1914. [CrossRef]

57. Fathi, S.J.; Austad, T.; Strand, S. Water-Based Enhanced Oil recovery (EOR) by "Smart Water" in Carbonate Reservoirs. In Proceedings of the SPE EOR Conference at Oil and Gas West Asia, Muscat, Oman, 16-18 April 2012; Society of Petroleum Engineers: Houston, TX, USA, 2012.

58. Myint, P.C.; Firoozabadi, A. Thin liquid films in improved oil recovery from low-salinity brine. Curr. Opin. Colloid Interface Sci. 2015, 20, 105-114. [CrossRef]

59. Eriksson, R.; Merta, J.; Rosenholm, J.B. The calcite/water interface: I. Surface charge in indifferent electrolyte media and the influence of low-molecular-weight polyelectrolyte. J. Colloid Interface Sci. 2007, 313, $184-193$. [CrossRef]

60. Pourchet, S.; Pochard, I.; Brunel, F.; Perrey, D. Chemistry of the calcite/water interface: Influence of sulfate ions and consequences in terms of cohesion forces. Cem. Concr. Res. 2013, 52, 22-30. [CrossRef]

61. Douglas, H.; Walker, R. The electrokinetic behaviour of Iceland Spar against aqueous electrolyte solutions. Trans. Faraday Soc. 1950, 46, 559-568. [CrossRef]

62. Fenter, P.; Geissbühler, P.; DiMasi, E.; Srajer, G.; Sorensen, L.; Sturchio, N. Surface speciation of calcite observed in situ by high-resolution X-ray reflectivity. Geochim. Cosmochim. Acta 2000, 64, 1221-1228. [CrossRef]

63. Prédali, J.J.; Cases, J.M. Zeta potential of magnesian carbonates in inorganic electrolytes. J. Colloid Interface Sci. 1973, 45, 449-458. [CrossRef]

64. Marouf, R.; Marouf-Khelifa, K.; Schott, J.; Khelifa, A. Zeta potential study of thermally treated dolomite samples in electrolyte solutions. Microporous Mesoporous Mater. 2009, 122, 99-104. [CrossRef]

65. Schramm, L.L.; Mannhardt, K.; Novosad, J.J. Electrokinetic properties of reservoir rock particles. Colloids Surf. 1991, 55, 309-331. [CrossRef]

66. Pokrovsky, O.S.; Schott, J.; Thomas, F. Dolomite surface speciation and reactivity in aquatic systems. Geochim. Cosmochim. Acta 1999, 63, 3133-3143. [CrossRef] 
67. Chen, G.; Tao, D. Effect of solution chemistry on flotability of magnesite and dolomite. Int. J. Miner. Process. 2004, 74, 343-357. [CrossRef]

68. Mihajlović, S.R.; Vučinić, D.R.; Sekulić, Ž.T.; Milićević, S.Z.; Kolonja, B.M. Mechanism of stearic acid adsorption to calcite. Powder Technol. 2013, 245, 208-216. [CrossRef]

69. Nalbach, M.; Raiteri, P.; Klassen, S.; Schafer, S.; Gale, J.D.; Bechstein, R.; Kuhnle, A. Where Is the Most Hydrophobic Region? Benzopurpurine Self-Assembly at the Calcite-Water Interface. J. Phys. Chem. C 2017, 121, 24144-24151. [CrossRef]

70. Kanicky, J.R.; Shah, D.O. Effect of degree, type, and position of unsaturation on the pKa of long-chain fatty acids. J. Colloid Interface Sci. 2002, 256, 201-207. [CrossRef] [PubMed]

71. Kumar, N.; Wang, L.; Siretanu, I.; Duits, M.; Mugele, F. Salt dependent stability of stearic acid Langmuir-Blodgett films exposed to aqueous electrolytes. Langmuir 2013, 29, 5150-5159. [CrossRef] [PubMed]

72. Haagh, M.E.; Siretanu, I.; Duits, M.H.; Mugele, F. Salinity-dependent contact angle alteration in oil/brine/silicate systems: The critical role of divalent cations. Langmuir 2017, 33, 3349-3357. [CrossRef] [PubMed]

73. Schwartz, D.K. Langmuir-Blodgett film structure. Surf. Sci. Rep. 1997, 27, 245-334. [CrossRef]

74. Bloch, J.M.; Yun, W. Condensation of monovalent and divalent metal ions on a Langmuir monolayer. Phys. Rev. A 1990, 41, 844. [CrossRef]

(c) 2019 by the authors. Licensee MDPI, Basel, Switzerland. This article is an open access article distributed under the terms and conditions of the Creative Commons Attribution (CC BY) license (http://creativecommons.org/licenses/by/4.0/). 